\title{
THE NATURE OF WISDOM: PEOPLE'S CONNECTION TO NATURE REFLECTS A DEEP UNDERSTANDING OF LIFE
}

\author{
T. ANDRINGA ${ }^{\mathrm{a}}$, N. ANGYAL ${ }^{\mathrm{a}}$ \\ ${ }^{a}$ University College Groningen, Hoendiepskade 23/24, 9718 BG Groningen, Nederland
}

\begin{abstract}
This paper shows that wise young adults formulate phenomenological intuitions about their relationship to nature that contain many references to advanced modern conceptions of life and 'core cognition'. Enactive cognition - summarized as "being by doing", focuses on a living agent's ability to remain alive through the selection of proper 'behaviors' from the set of coping and co-creating behaviors. Co-creating agents satisfy their immediate needs while improving the quality of the environment on which their need satisfaction depends. They contribute to a thriving environment in which long-term need satisfaction is greatly facilitated. We refer to this skill as 'agent adequacy' that we associate with wisdom. Inadequate agents continually cope with need satisfaction. They might end up in a 'coping trap' where their coping strategies gradually degrade the habitat on which their long-term viability depends. In doing so, they lock themselves in an endless cycle of marginal need satisfaction. We propose concise and precise formulations of three fundamental concepts of the agent-environment relation: adequacy (the ability to satisfy needs in the short and long term), connectedness (referring to a personal bond with other agents or nature as a whole that is experienced as mutual), and beauty (that derives from the environment's ability to produce fragile perfection that is a measure of environmental quality). Analysis of our interviews showed that our (rather wise) group of respondents addressed all three fundamental concepts. We conclude that our theoretically derived agent-environment framework is exemplified by the human-nature relation.
\end{abstract}

Keywords: enactive cognition, agent adequacy, wisdom, life, nature, beauty, connectedness, peak experiences, phenomenology, core cognition, need satisfaction, self-actualization.

\section{Introduction}

This paper shows that (wise) young people formulate phenomenological intuitions containing many references to advanced modern conceptions of "life" and wisdom about their relationship to nature. We combine theoretical work on the origins of cognition from the perspective of enactive cognition (Andringa, van den Bosch, \& Wijermans, 2015) with an (initially) unrelated thesis addressing the phenomenology of connectedness to nature (Angyal, 2018). In our discussions we realized that the interviews with (apparently) wise young adults, on which the thesis 
was based, provided many insights and clear formulations about the properties of the connection between a (living) agent and its environment. Here we connect our theoretical approach to the insights conveyed in the interviews and we show a high level of coherence.

Enactive cognition (Di Paolo, Rohde, \& De Jaegher, 2010; Thompson, 2004, 2007; Varela, Thompson, \& Rosch, 1993) is an approach to cognitive science that starts from defining properties of life as initially formulated in the field of "autopoiesis" (Maturana \& Varela, 1991). Autopoiesis means self-production and refers to life's central ability to maintain and produce itself without external direction. Self-production and self-perpetuation occur on the level of living individuals, but the interdependence of living individuals in habitats and ecosystems and the interdependence of the different ecosystems on Earth entails that life as a whole - the biosphere - produces and maintains itself as well. Within enactive cognition, individuals are referred to as "living agents" or "agents" for short. Agents, unlike rocks or hurricanes, are sources of self-initiated activities: "behaviors". Agents are free to select their behaviors as long as these behaviors keep them alive (death obviously ends the self-initiation of behavior). Enactive cognition can therefore be summarized as "being by doing" (Froese \& Ziemke, 2009).

The enactive framework allows us to develop cognitive science from the defining properties of life ( 5 Gya, $5 \times 10^{9}$ years ago) and hence from well before the advent of brains and neurons (about 0.5 Gya), and even multicellular (1 Gya) and eukaryotic life (2.4 Gya). Enactive cognition allows us to study key aspects of cognition without human and cultural biases and idiosyncrasies. In fact, what we summarize below is the cognition shared by all of life that we refer to as "core cognition" (Andringa et al., 2015). We argued that human cognition is scaffolded, via many evolutionary innovations, on core cognition and manifests core cognition in its own idiosyncratic and culturally colored ways. Still, we argue and demonstrate that references to core cognition emerge both spontaneously and clearly in conversations with young individuals who address their connection with nature.

In this paper, we do something that is unusual for psychology: we do not start from a human subject, rather we start from an abstract living entity - the agent that ensures its own existence through its own doing. And it does so by attending to its own needs and only on success promotes an environment in which need satisfaction is facilitated. In doing so we aim to derive a concise and precise formulation of fundamental concepts of the human-environment relation: adequacy, connectedness, and beauty.

In the next section, we first outline core cognition and identify aspects that we expect to feature in conversations about people's connection to nature. This leads to a number of concepts that we use to analyze the interviews. After the methods section, we present the results as examples of how the expected concepts are formulated by our participants. We conclude with a discussion. Note that when we talk about "agents" we refer to the domain of core cognition: cognition shared by all of life. When we refer to humans, e.g., participants or young adults, we are in a human context in which core cognition is implemented in uniquely human and cultural ways. 


\title{
Theoretical Framework: Enactive Cognition
}

\author{
Agent Adequacy
}

Because life self-produces, it is not directed by external forces. Nevertheless, it is subject to the environmental conditions that may promote or impede its viability. Living agents exist on a viability axes with languishing (low viability) on one extreme and thriving (high viability) on the other extreme. In our previous paper (Andringa et al., 2015, figure 2) we described how a number of key concepts of cognitive science arose from these defining properties of life.

In particular, we separated two modes of existence: the coping-mode that aims to protect existence by satisfying pressing needs, and the co-creation mode that aims to contribute to an environment in which the occurrence of pressing needs and hence the activation of the coping mode - is ever less likely. Success for the coping mode entails satisfaction of immediate needs, and with that its own deactivation. For the co-creation mode, the measure of success is its own continued activation, and hence a thriving state characterized by continually satisfied needs. Therefore, a key difference between the two modes is an association with (coping) states that agents want to avoid or end, and (co-creation) states that the agent aims for and wants to perpetuate. We refer to "agent adequacy" as the ability to be in the co-creation mode often and to return to it quickly when brought in the coping mode. Vice versa, "agent inadequacy" refers to the inability to avoid or end states that the agent does not want to be in.

"Intelligence" as the ability to solve (i.e., end) problems, is a key skill of the coping mode, and "power" defined as "the ability to reach intended results" (Russell, 1938), is a measure of how well an agent copes. Negative emotions and moods, those that we want to end and avoid, are naturally associated with the coping mode (Andringa et al., 2015). So an agent that is driven by deficiency needs (Maslow, 1954) is in the coping mode. Although the purpose of the coping mode is to be discontinued as soon as possible by satisfying pressing needs, this is preconditioned on the successful resolution of the deficiency needs. If the coping agent solves one problem by creating another problem, it can inadvertently ensure its own continuation. We refer to this as a "coping trap".

Agents in a coping trap are often self-responsible for being and remaining in the coping mode by their inability to satisfy needs without creating new or more (future) problems/needs. Being and remaining in a coping trap is a telltale indicator of the agent's inadequacy. An inadequate agent maintains a situation it rather wants to end. And it typically does so because of the inability to select behaviors that would end the unfavorable situation. A richer behavioral repertoire, an increased sense of realism, and improved strategies to execute effective behaviors when appropriate makes the inadequate agent (more) adequate. Learning counterproductive strategies and sticking to them (perhaps because the strategies provide some fleeting benefits) increases the inadequacy. Learned helplessness (Maier \& Seligman, 1976) can be interpreted in terms of a coping trap since it only occurs for fairly difficult behaviors under the agentic control (Andringa, van den Bosch, \& 
Vlaskamp, 2013). When agents have accepted that their behaviors are pointless in addressing their needs, they have locked themselves in a coping trap.

In this paper we refer to "wisdom" as "the ability to produce broadly beneficial desired results while taking the full consequences of behavior on the habitat into account" (Andringa et al., 2015). Wisdom allows agents to contribute to the environment in ways that allow the habitat to recover and grow, despite the agent also taking from it to satisfy its needs. This is a definition of wisdom that is not anthropocentric and, in fact, allows individuals of any species to act wisely. A positive sum total of the subtractions from and contributions to the habitat allows the habitat to grow and flourish. Hence it is ever easier for the agent to satisfy its needs without having them become pressing and thus activating the coping mode. Wise agents manifest a deep "understanding" through their ability to work with the tendencies in their habitat to promote its flourishing. While the inadequate agent proves its lack of understanding through the inability to foresee the consequences of its own activities, the wise agent is able to enact its behaviors by avoiding (unnecessary) harm and promoting habitat growth. Wise agents therefore rarely end up in the coping mode through their own doing: they are adequate agents.

\section{Development of Wisdom}

In a paper called "Learning autonomy in two or three steps: linking open-ended development, authority, and agency to motivation" (Andringa et al., 2013) we separated three growth phases. In Phase 1 the agent learns to bring its body under control as a suitable vessel for sense-making and purposeful interaction with the environment. In Phase 2 it learns to become an adequate thinker, actor, and problem-solver by learning from whatever its environment (for humans, society) offers. Preconditioned on the success of Phase 2 and hence on becoming sufficiently adequate, the agent progresses to learn to effectively co-create a rich and flourishing habitat (for humans, its natural and societal environment).

The transition from Phase 2 to Phase 3 corresponds to what Ardelt (2000) describes as a difference between the use of "intellectual knowledge" and "wisdom-related knowledge". The goals of the intellectual knowledge strategies are associated with the accumulation of (culturally shared) knowledge and information, and the discovery of new truths. It is focused on the mastery of the outside world through learning how to do the correct things efficiently and without error. It should result in making the world more certain, regular and predictable so that one's future self is better able to deal with the expected. Overall, it improves mastery.

In contrast, wisdom-related strategies are associated with the development of a deeper understanding of salient phenomena and events, and the (re)discovery of significant old truths. It is focused on interpretative knowledge and the question whether or not to influence things. Wisdom results in a mastery of the inner world from self-imposed limitations and the acceptance of uncertainty, irregularity, unpredictability, and the impermanence of the world (both cultural and natural) as a resource. A wise person learn from dealing with the unexpected and still unknown. Overall, wisdom improves one's ability to work with the tendencies of the 
world as opposed to frantically controlling and curtailing it. In short, it is co-creation (Andringa et al., 2013).

The skill to co-create is also known as the Daoist term "Wu wei" that means something like "act naturally", "effortless action", or "nonwillful action" (Littlejohn, 2003). Additionally, Maslow (1954) refers to co-creation as being-cognition (B-cognition), which he considered to be essentially associated with selfactualization. Our subjects were selected on the expectation that they had developed a deeper understanding of their relationship to nature, and hence we expected them to be rather wise and self-actualizing.

\section{Pervasive Optimization and Connectedness}

We have referred to co-creation as "pervasive optimization" (Andringa et al., 2013). Pervasive optimization is what keeps friendships viable. It does not involve scripted interactions or control. Quite the contrary: it relies on multiple small contributions to each other's viability. For example, being interested in each other, showing at random moments that you care, and providing help and support when appropriate, while leaving each other free. Maintaining healthy friendships is " $\mathrm{Wu}$ wei" in action. More generally, pervasive optimization allows agents to thrive in a habitat that is continually maintained and enriched by countless and nearly effortless pervasive optimizations by the living agents that constitute it.

Co-creation (pervasive optimization, $\mathrm{Wu}$ wei, or self-actualization) allows the (adequate) agent to form a mutualistic (mutually beneficial) relationship with its habitat. The inadequate agent is preoccupied with its own pressing needs and sees the habitat more as a resource for need satisfaction and self-enhancement than as an environment to be cared for as a basis for long-term need satisfaction. Adequate agents satisfy their needs without letting them develop into pressing - copingmode activating - needs. They do so by continually investing in habitat quality for (shared) long-term viability. Compared to inadequate individuals, they have developed a richer, more "lived", more personal/idiosyncratic, and more tested understanding of their habitat and their natural and cultural environment. Our subjects experience this as a sense of connectedness, which most of them formulate in unique and deeply personal terms.

\section{Role of Beauty}

When we studied the interviews, we noticed a fair number of references to an initially vague concept that we referred to as "beauty". In the beginning this puzzled us. Why were our participants interested in beauty and why did they connect beauty to value? More generally, why would an agent's interest be attracted to beauty and how could it indicate value in an enactive cognition framework? The beauty of a flower, a natural scene, and even a work of art is typically associated with combinations of concepts like fragility, perfection, complexity, interdependence, fleetingness, impermanence, health, and harmony. These concepts refer as much 
to the beautiful object as they refer to the quality of the environment that allowed the beauty - as fragile perfection - to emerge.

Hence, the beauty of an environment is suggestive of the environment's qualities to produce fragility, perfection, complexity, interdependence, and harmony. Since the beautiful is generally fragile and fleeting, it requires constant re-emergence to be abundantly visible. Hence prominent beauty is a sign of an environment that promotes highly "optimized" states of existence, which includes high viability states. In retrospect, we could have expected a role for a concept like beauty in our theoretical framework. In this paper we investigate how our informants refer to our new conception of beauty.

\section{Expectations}

Figure 1 provides an overview of our theoretical framework. Agents need to satisfy short- and long-term needs. Short-term needs are associated with keeping the individual agent alive. The inadequate agent, mainly through its own inability, struggles with continually unsatisfied pressing needs and is preoccupied with knowledge and strategies that give it more control over its situation, which, for humans, Ardelt (2000) refers to as intellectual knowledge use and Maslow as "deficiency cognition”. Adequate agents have learned how to satisfy pressing needs. They are interested to develop and improve pervasive optimization skills that promote the quality of their environment/habitat. This way, needs can be met while enhancing habitat quality. Ardelt refers to this as the use of wisdom related knowledge and Maslow as "being cognition”. Note that this process of habitat co-creation has allowed the biosphere to develop from an initially small and fragile state to its current robustness and scope.

We expect that only adequate agents - in our case relatively wise, young adults - feel and act on the inclination to develop high quality pervasive optimization (co-creation) strategies. Inadequate agents are preoccupied with pressing need satisfaction and are, by and large, unaware of these strategies and even of the need for them.

Figure 1 provides an overview of the theory and the resulting key terms. Note that these have been derived from arguments that pertain to living agents in general. In the last theory subsection we show how these key terms pertain to humans.

\section{Wisdom in Humans}

In the derivation of the key components of the (generalized) wisdom concept we separated agent adequacy, connectedness, and beauty. Is it possible to connect these concepts to an existing conceptualization of wisdom? We think we can. Ardelt has developed a Three-Dimensional Wisdom Scale (Ardelt, 2003) that separates wisdom in cognitive, affective, and reflective components. However, some of these components can also be interpreted in terms of adequacy, connectedness, and beauty. Below we use quoted phrases from Ardelt (2003) to show this. 


\section{Overview of Theoretical Key Terms}

Figure 1

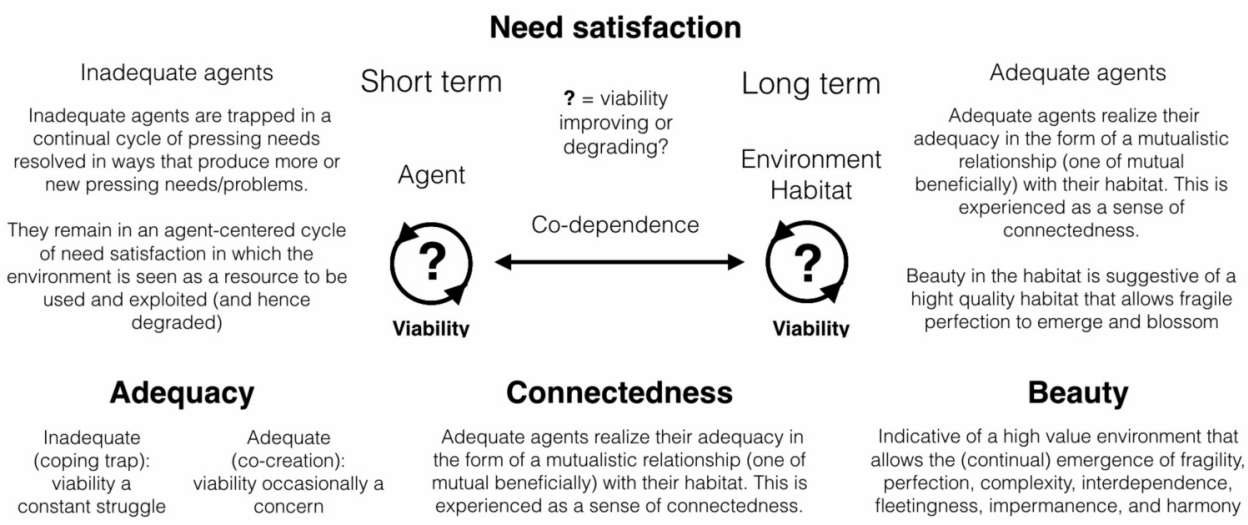

Note. In our analysis we focus on formulations suggestive of agent adequacy, connectedness to the habitat, and perceiving beauty in relation to environmental value. Together these three concepts span important features of the concept of agent wisdom.

Adequacy refers to the ability to resolve pressing problems and to avoid coping traps. Hence "an inability to make important decision despite life's unpredictability and uncertainties" is contraindicative. Likewise, the observation "Things often go wrong for me by no fault of my own" or "I either get very angry or depressed if things go wrong" are indicative of prominent coping and perhaps a coping-trap. On the other hand, "A perception of phenomena and events from multiple perspectives" and frequent "self-examination, self-awareness, and self-insight" are suggestive of agents that try to make the most of a complex and unpredictable situation.

Connectedness refers to a personal bond with other agents or nature as a whole that is experienced as mutual. Contraindications of connectedness are remarks like "It's not really my problem if others are in trouble and need help" and "a tendency to see the world as either black or white" or us versus them. But "the presence of positive, caring, and nurturant emotions and behavior toward others" and "the absence of indifferent or negative emotions and behaviors toward others" are indicative of connectedness.

Beauty refers not so much to beautiful objects or scenes as such, but to the value we attribute to the environment that spawned the beauty and to our intrinsic motivation to care and connect. Remarks like "In this complicated world of ours, the only way we can know what's going on is to rely on leaders or experts who can be trusted" is a contraindication because it indicates an external locus of control. Similarly, agreeing with the statement "Life is basically the same most of the time" suggests an inability to see value in everyday situations. Overall an unawareness of ambiguity and uncertainty in life makes it difficult to appreciate the fleeting, uniquely harmonious, and fragile perfection of beauty. In contrast, appreciating beauty drives "the ability and willingness to understand a situation or phenomenon thoroughly". 
We will use these three conceptions of adequacy, connectedness, and beauty as our guideline to analyze our participant's formulation of their relationship to nature.

\section{Methods}

At the basis of this paper is a qualitative, phenomenological study we conducted in Groningen in the spring of 2018. This study was part of a bachelor thesis titled "The phenomenology of connectedness: An inquiry into the human experience of the natural world" (Angyal, 2018). It investigated the richness of people's experience of nature. Although the qualitative study was conducted for a purpose other than the present article, we found the material ideal to combine with our theoretical work on wisdom. The study consists of twelve in-depth interviews with selected individuals living in Groningen, that are reanalyzed using our formulations of adequacy, connectedness, and beauty. For a more detailed description of the methodology refer to (Ibid.).

\section{Participants}

We made a non-representative sample of the general population, consisting of individuals from our circle of friends and acquaintances. In the phenomenological tradition, it is homogeneity (as opposed to heterogeneity) among the participants that is encouraged for a better understanding of the general "lived experience" we seek to study (Alase, 2017). We wanted them to possess: 1) introspection and the ability to critically reflect on themselves; 2) awareness about matters concerning the environment and human-nature relations; and 3) affinity for an in-depth conversation on a philosophical topic. We aimed to select people who had meaningful stories to tell about their personal experience of nature. The fact that we had previous contact with most of the participants helped them feel comfortable enough to share their feelings and deep insights into such experiences. This helped to reach considerable depth in an interview of less than 60 minutes. Among our participants, nine were university students and three worked as artists. All had or were working towards a bachelor degree. We contacted each participant personally with a short description of the research project and their proposed role in it. We settled on twelve participants (six males and six females) between the ages of 20 and 50 (mean age was 26 year).

\section{Procedure}

The interviews took place at different (primarily outdoor) locations chosen by the participants. We recorded nearly hour-long conversations and transcribed them in full for analysis. The main method we applied during the interviews and the subsequent analysis was a phenomenological approach, following the instructions of Hycner (1985), Moustakas (1994), and Lester (1999). In Moustakas' (Moustakas, 1994) definition, the "empirical phenomenological approach" is an attempt to "return to experience in order to obtain comprehensive descriptions that 
provide the basis for reflective structural analysis that portrays the essences of the experience". We focused on depth rather than structure during the interviews, aiming to bring out the richness of our participants" experience of nature.

The first part of the interview aimed to help their reflection process and to connect participants to their senses, their physical-emotional states, and the current place. The second part of the interviews took a less sense-based and more philosophical turn, following the Hegelian interpretation of phenomenology, which maintains that a phenomenon is "knowledge as it appears to consciousness" (Ibid.). Therefore, question 7 was intended to stimulate participants' intuition. All questions, and the structure of the interview are presented in Table 1.

These questions investigated participants" insights on human-nature relationships and reveal their thoughts about and attitudes towards the natural world. The interviews also had a third, final part, which consisted of a text analysis of naturebased spiritualities. However, for our current purpose, we are only concerned with the data and results from the first two parts of the interviews.

\section{Results}

The re-analysis of the interview transcripts (using our current conceptualization of adequacy, connectedness, and beauty) confirmed our participants' deep

Interview Structure and Associated Questions

Part 1 - Connecting participants to their senses and their physical-emotional states

1) How are you feeling at the moment?

2) (How) does this place influence how you feel right now?

3) Why did you choose this particular place?

4) How does it make you feel?

5) Is there anything about this place in particular that you enjoy?

6) Do you come here often?

Part 2 - Less sense-based and more philosophical questions

7) When you think of nature, what comes to your mind first?

8) Besides this particular place, do you have general affinity for nature?

9) Do you think human life is qualitatively different from the lives of non-human beings? If yes, how so? If no, why not?

10) Do you feel part of a cycle of life? Do you perceive cycles in life?

11) Do you attribute any intelligence or wisdom to non-human beings? How would you define their concepts?

12) Are you concerned about the state of the environment? Does, for instance, biodiversity decline, species extinction, or ocean pollution affects you emotionally?

13) Do you consider yourself an environmentally conscious person?

14) If yes, how so? Do you sometimes reflect on how your 'being in the world' affects the rest of the world? 
understanding of life as wise and self-actualizing agents including the associated peak experiences (Maslow, 1962a, 1962b). We scored wisdom in terms of adequacy, connectedness, and beauty and summarized the results in Table 2.

Each interview was analyzed in terms of: 1) traits of adequacy, 2) experiences of connectedness, and 3) conceptions of beauty. Adequacy was scored in terms of selfreflection [SR], compliance with reality [CR], peak experience [PE], and pervasive optimization [PO]. Connectedness in terms of descriptions of the type of bond mentioned (quiet bonds experienced in everyday nature, peak experiences in wild nature, or a more philosophical/cerebral approach). Beauty is scored in a variety of formulations. All score categories are explained in more detail below. Based on our theoretical framework, those participants who showed indications of adequacy, connectedness, and beauty were identified as wise (agents).

Table 2

Types of Adequacy as Outlined in the Subsection Adequacy

\begin{tabular}{|l|l|l|l|}
\hline Participants & \multicolumn{1}{|c|}{ Adequacy } & Connectedness & \multicolumn{1}{c|}{ Beauty } \\
\hline Paula & Yes [SR] & Yes [quiet bond] & Yes [awe] \\
\hline Sam & Yes [SR] & Yes [quiet bond] & Yes [appreciation] \\
\hline Maria & Yes [SR] & Yes [wild nature] & Yes [appreciation] \\
\hline Tom & Yes [SR; PO] & Yes [quiet bond] & $\begin{array}{l}\text { Yes [hard to grasp; } \\
\text { spiritual] }\end{array}$ \\
\hline Ron & Yes [SR; CR;] & Yes [quiet bond] & $\begin{array}{l}\text { Yes [connection; } \\
\text { appreciation] }\end{array}$ \\
\hline Luke & Yes [SR; CR] & Yes [quiet bond] & Yes [perfect] \\
\hline Jake & Yes [SR; PE; CR; PO] & $\begin{array}{l}\text { Yes [quiet bond and } \\
\text { peak experience] }\end{array}$ & $\begin{array}{l}\text { Yes } \\
\text { [spiritual; motivation] }\end{array}$ \\
\hline Kate & Yes [SR; CR; PE] & $\begin{array}{l}\text { Yes [quiet bond and } \\
\text { peak experience] }\end{array}$ & $\begin{array}{l}\text { Yes [appreciation; } \\
\text { value; protection] }\end{array}$ \\
\hline Lotte & No & No & ? No \\
\hline Sanne & Yes [SR; CR] & Yes [quiet bond] & $\begin{array}{l}\text { Yes } \\
\text { [complexity; mystery] }\end{array}$ \\
\hline Roland & Yes [SR; CR; PO] & Yes [philosophical] & Yes [harmony; love] \\
\hline Nora & Yes [SR; CR; PE] & $\begin{array}{l}\text { Yes } \\
\text { [peak experience] }\end{array}$ & \begin{tabular}{l} 
Yes [protection; value] \\
\hline
\end{tabular} \\
\hline
\end{tabular}

Note. $\mathrm{SR}=$ self-reflection; $\mathrm{CR}=$ compliance with reality; $\mathrm{PE}=$ peak experience; $\mathrm{PO}=$ pervasive optimization; for an explanation of the types of connectedness and beauty see the subsections on Connectedness and Beauty. 
As Table 2 demonstrates, eleven out of the twelve participants showed features of adequacy, experienced a sense of connectedness, and had deep insights about beauty in relation to their nature experience. We also identified different expressions of adequacy, connectedness and beauty, which we will discuss below. Only one participant did not score on any dimension, she will be addressed last.

\section{Adequacy}

We summarized indications of adequacy into four categories: 1) self-reflection; 2) compliance with reality; 3) peak experiences; and 4) pervasive optimization.

\section{Self-reflection [SR]}

One of the recurring characteristics was the ability to critically reflect on their thoughts, feelings, and actions in connection with nature. Their reflections (Table 3 ) entailed their sense of connection (or disruption) with the environment.

Table 3

Evidence of Participants' Ability for Deep Self-Reflection

\begin{tabular}{|l|l|}
\hline Participant & \multicolumn{1}{c|}{ Quotes } \\
\hline Sanne & $\begin{array}{l}\text { (...) living on this boat, I feel this connection and yet disruption with nature. } \\
\text { Sometimes I feel like an outsider to the water. }\end{array}$ \\
\hline Kate & $\begin{array}{l}\text { I realise that it makes me so calm when I'm outside in nature, somewhere more } \\
\text { further away from the rest of society (...) that's when I think I'm most happy. }\end{array}$ \\
\hline Sam & $\begin{array}{l}\text { I feel stuff, I do stuff, but it's nothing compared to the infinite greatness of what } \\
\text { is out there. That's how I usually feel. }\end{array}$ \\
\hline
\end{tabular}

As the quotes above suggest, participants described their state-of-being in relation to their environment. That is, they show a developed ability to view themselves essentially embedded in the natural landscape that they inhabit.

\section{Compliance with reality [CR]}

Another indication of adequacy was a strong tendency among the participants (Table 4) to rely on their experience for a grounded perception of reality, rather than ideologies and consensus-based understandings of the world.

These quotes reflect participants' frustration and apprehension about matters concerning the environment. They seem to resist popular and often simplified interpretations of reality - here exemplified by the "fear paradigm" fueling alarm about the state of the environment. Instead, they support independent thinking and an acceptance of complexity that is inherent to life. 
Evidence of Participants' Tendency to Comply with Reality

\begin{tabular}{|l|l|}
\hline Participant & \multicolumn{1}{c|}{ Quotes } \\
\hline Ron & $\begin{array}{l}\text { I'd rather people not dive into the fear paradigm, which...imposes the negative } \\
\text { experiences, which are much less than the positive. Creating an illusion of fear } \\
\text { that's actually not happening. }\end{array}$ \\
\hline Jake & $\begin{array}{l}\text { There is a lot of people who disagree with evolution. It doesn't matter how } \\
\text { many bones we dig up, how many scientists look at rocks that sedimented over } \\
\text { the years...all of that geographic science is in large denial. }\end{array}$ \\
\hline Sanne & $\begin{array}{l}\text { I think a lot of times we should just let it [nature] be what it is (...) this utopia } \\
\text { that we build around it as if nature could be the saviour of everything. As if } \\
\text { nature would be this good thing. No, nature can be hard as well, nature can be } \\
\text { destructive. }\end{array}$ \\
\hline
\end{tabular}

\section{Peak experience [PE]}

Some of the accounts describing participants' connection with the natural world involved experiences of high emotional intensity, the presence of a powerful or mystical quality, and the realization that something significant happened to them. This is what Maslow (1964) called a "peak experience" - a common occurrence among self-actualizing people and perhaps even characteristic of self-actualization. These references occurred spontaneously and could sometimes also be scored as a sign of connectedness or in relation to beauty (Table 5).

It becomes clear from these accounts that "peaking individuals" experience an intensifying and broadening of their sense of self while being in typically "wild"

Table 5

Examples of Peak Experiences in Participant Accounts

\begin{tabular}{|l|l|}
\hline Participant & \multicolumn{1}{c|}{ Quotes } \\
\hline Kate & $\begin{array}{l}\text { We had this one walk when we were climbing this one volcano. (...) you just feel } \\
\text { so humble and alive at the same time, 'cause you had this very strong wind at } \\
\text { the top and you're just looking over this out-of-earth landscape. (...) and that } \\
\text { just makes you feel really overwhelmed. But also really alive. }\end{array}$ \\
\hline Nora & $\begin{array}{l}\text { (...) in the waves, perhaps I feel more one with all the elements that are around } \\
\text { me. And I take them as they come. (...) it's a process of trust in those elements } \\
\text { that you don't quite understand and you absolutely cannot control but feel very } \\
\text { much part of you when you're communicating with them. }\end{array}$ \\
\hline Jake & $\begin{array}{l}\text { I've never felt more alive than when I've been on my own a few times in a natu- } \\
\text { ral setting, sometimes vulnerable, sometimes not so vulnerable. (...) having this } \\
\text { kind of mystical experiences...as having this power over you. It puts you in } \\
\text { place, if you feel it. }\end{array}$ \\
\hline
\end{tabular}


natural settings. In Angyal (2018), we identified two different types of nature: wild and everyday. We noticed that peak experiences occurred in physically captivating nature settings ("wild nature"), as opposed to the environment participants are normally exposed to ("everyday nature").

\section{Pervasive optimization [PO]}

Taking an all-addressing, active, and holistic stance concerning the environment was a common characteristic of adequacy among the participants. As Table 6 shows, they view themselves as individuals (and humanity as a whole) as relational (rather than isolated entities) for which they feel a shared responsibility. That is, they understand the underlying interdependence in the structure of reality, and thus the significance of their actions on others or the whole.

Table 6

Evidence of Participants' Tendency for Pervasive Optimization

\begin{tabular}{|l|l|}
\hline Participant & \multicolumn{1}{c|}{ Quote } \\
\hline Roland & $\begin{array}{l}\text { This is literally our purpose, I call it 'Spreading love', but in a very biological } \\
\text { sense it just means benefitting the organism. (...) the way we cells benefit the } \\
\text { organism, that is, the world we live in, is to live in harmony with it. }\end{array}$ \\
\hline Tom & $\begin{array}{l}\text { To understand stuff in a whole, it's easy to say that, but it's much harder to do. } \\
(\ldots) \text { in economics, we have this compartmentalised thinking. It's just cause it's } \\
\text { easier to make theories that way (...) it's actually way more complicated. }\end{array}$ \\
\hline Nora & $\begin{array}{l}\text { I think whatever I project out...can make just a little bit of a difference. And } \\
\text { whatever thoughts or approach I have to life, it's being sent out in some way. }\end{array}$ \\
\hline Luke & $\begin{array}{l}\text { (...) when you are acting from a compassionate, open-hearted, and loving source, } \\
\text { you will have that effect on other beings around you as well....people like to fol- } \\
\text { low others so you can plant seeds by your actions. }\end{array}$ \\
\hline
\end{tabular}

\section{Connectedness}

During the first analysis of the transcripts (before the current reanalysis), the sense of connectedness emerged as the most meaningful lived experience of nature. Table 7 provides some accounts of feeling connected to and a part of the wide web of relations that constitute ecosystems and the biosphere (and nature in general). In our first analysis of the transcripts we identified two types of connectedness: 1) "Peak experiences in the wild"; and 2) "Quiet bonds of the everyday". As Table 2 demonstrates, three participants reported having had peak experiences in the past, typically in wild nature settings. These were spontaneous, unprovoked responses. A further eight participants had stories of connectedness, of a quieter quality, in everyday settings (hence the "Quiet bonds of the everyday"). One participant had a philosophical theory and not a personal experience to tell about the nature of 
connectedness, and one another participant gave no indication of an experience of this sort.

Table 7

Participant Accounts of Connectedness

\begin{tabular}{|l|l|}
\hline Participant & \multicolumn{1}{c|}{ Quote } \\
\hline Paula & $\begin{array}{l}\text { I feel like when I'm connected to the environment the energy is flowing, like I } \\
\text { feel part of it, as if we were one, not just we but the world and me. Just that we } \\
\text { are connected and I'm not an isolated person apart from everything what is hap- } \\
\text { pening, that we are one, like a big organism. }\end{array}$ \\
\hline Luke & $\begin{array}{l}\text { I definitely feel that it [interacting with non-human beings] puts me at ease. I } \\
\text { think they like it too, because I feel that their energy is positive when I talk to } \\
\text { them. I think... it's all about intention of course. It puts me into a relation. }\end{array}$ \\
\hline Roland & $\begin{array}{l}\text { We are not universes onto ourselves, but we are part of a greater, what I call, } \\
\text { organism. We come from this earth, almost literally. }\end{array}$ \\
\hline Sanne & $\begin{array}{l}\text { There's one lady duck who would always come around... at some point she was } \\
\text { just sitting on a deck and I just sat down and for ten minutes we just looked at } \\
\text { each other...To just accept we both are, we are together, and we're happy about } \\
\text { that. And that can be a very long process. Each animal, each human is getting to } \\
\text { know each other. }\end{array}$ \\
\hline
\end{tabular}

\section{Beauty}

The concept/idea of "beauty" emerged in the interviews often implicitly, in relation to a number of other concepts such as "protection", "value", "connection", "appreciation", "perfect", and "spiritual" with motivating effect on self (for more examples refer to Table 2). Most of the participants emphasized the importance of minimizing the harm or unnecessary influence people inflict upon the environment. Rather, they suggest acknowledging the inherent value and beauty of nature in direct experience with it. It means establishing intimate connections with the nonhuman inhabitants of our environment, appreciating their value and role in the complex web of relations. Table 8 shows that participants formulate it in diverse ways.

\section{Lacking wisdom}

There was one participant whose level of experience and understanding of nature did not reach the depth of the other participants. Her reflections were superficial and clichŭd. They revealed less about her own feelings and original thinking and more about her learned and commonplace responses. As Table 9 suggests, even her most significant remarks reflect a shallow kind of environmental awareness and lack the sense of connectedness present in the other accounts. 
Participants' Conceptions on Beauty

\begin{tabular}{|l|l|}
\hline Participant & \multicolumn{1}{c|}{ Quote } \\
\hline Nora & $\begin{array}{l}\text { I think if we learn to spend more time within nature and learn to value that more } \\
\text { than the way that we are currently doing, which is very technology-based... we're } \\
\text { gonna start really losing touch with this other side of life which is very real and } \\
\text { true. Whenever you can, go out, feel what it feels like to be really in it. }\end{array}$ \\
\hline Kate & $\begin{array}{l}\text { That is really important to use that, that appreciation. You can appreciate it } \\
\text { because you have this idea of values of what is beautiful and what is not. I } \\
\text { think nature has a certain value and we should actively preserve it and that we } \\
\text { will only realise it's value once it's gone. }\end{array}$ \\
\hline Tom & $\begin{array}{l}\text { This other element of things, that are hard to grasp onto like beauty and ritu- } \\
\text { als... you respect something that is beautiful. }\end{array}$ \\
\hline Jake & $\begin{array}{l}\text { (...) the aesthetics of a mountain, when climbing a mountain, the aesthetics of } \\
\text { a rock, the story of the geology of what I'm experiencing, the texture, and the } \\
\text { wind, and also the excitement of nature... spiritual is finding beauty or some } \\
\text { essence, or some aesthetics, which is very appealing, which motivates me. That } \\
\text { could be a spiritual experience. }\end{array}$ \\
\hline
\end{tabular}

Table 9

An Example of a Non-Wise Participant

\begin{tabular}{|c|l|}
\hline Participant & \multicolumn{1}{c|}{ Quote } \\
\hline \multirow{2}{*}{ Lotte } & $\begin{array}{l}\text { When I go hiking... I once lost my plastic bottle out of my backpack and I felt so } \\
\text { bad that I took another one which I just found on the way to make up for the } \\
\text { one I lost. } \\
\text { People need to take their own cotton bags to the market and have their stuff put } \\
\text { in there instead of plastic. Or, the plastic bags should be made out of something } \\
\text { else. } \\
\text { When I was a kid, I was very much connected to nature. To little dwarfs. When } \\
\text { we went into the forest I imagined them sitting behind the trees because they } \\
\text { were afraid of humans, of course. They didn't show but... I imagined them and } \\
\text { build in the bottom of trees houses for them. }\end{array}$ \\
\hline
\end{tabular}

\section{Discussion}

This paper addresses two related topics. On the one hand, it aimed for more conceptual clarity of the relationship between enactive cognition as a general - nonanthropocentric - framework for living agents and anthropocentric definitions of wisdom and self-actualization. On the other hand, we investigate whether the resulting conceptualization complied with the content of in-depth interviews with rather wise and self-actualizing (young) individuals. We showed that our participants produced rich descriptions of their relationship to nature and they manifested 
a deep understanding of nature and their relation to it. We expected this depth of understanding to be present in rather wise, self-actualizing individuals for whom developing ever-better co-creation strategies was more important than focusing on coping strategies.

Since our participants were selected to be rather wise, we had only one participant who was unable to produce non-clichŭd responses. She produced neither indications of wisdom nor self-derived unique insights of her relationship to nature. She was a very useful participant who showed that producing in-depth responses and demonstrating a deep understanding of our relation to nature might not be easy at all. However, those who did develop it, agree on an essential and rich interdependence between their own thriving and that of the environment. This suggests that true sustainability might be impossible without wisdom.

We showed that our wise participants produced, in the fairly structured context of the interview, a rich tapestry of formulations that make complete sense from the theory of enactive cognition. In particular, we were happy to observe references to agentic adequacy, connectedness, and beauty. We identified adequacy as a precondition to developing a more meaningful and in-depth relationship to nature. And we concluded that adequacy, in so far as apparent from the human-nature relation, is expressed in at least four different ways: self-reflection, compliance with reality, peak experiences, and pervasive optimization. Each of these topics is worth further investigation and they might be intimately connected. Peak experiences, for example, might be associated with all three dimensions of agent wisdom and they might be associated with the gradual deepening of understanding of the world.

When we first perused the interview texts, we were surprised by the prominence of connectedness. Although we investigated individual's connection to the natural world, we did not expect that connectedness would emerge as a coherent concept. For the current paper, we recognized that connectedness is central to our model of the agent-environment relation, and hence an essential aspect of wisdom. Something similar was true for beauty. That also appeared regularly. With the help of our theoretical model we realized that beauty should not be interpreted as referring to beautiful objects or scenes as such, but to the value we attribute to the environment that spawned the beauty and the intrinsic motivation to care and connect this environmental value elicits. Again, this is a central feature of the agent-environment relation.

We are not aware of other theoretical frameworks, rich enough to produce expectations with similar precision, which can explain or predict the key features of the agent-environment relation as we have done here. This paper exemplified this with a rich tapestry of insights in the human-nature relation. Additionally, we showed that (although none of our participants had any knowledge of enactive cognition) the combined, richly formulated responses complied with its central ideas.

As a qualitative study, we cannot prove or disprove any hypothesis. Qualitative studies excel in the discovery and formulation of new concepts and in improving formulations of existing concepts; and that is what we did. Our subject group was clearly rather wise, but we cannot say whether our subjects are representative of 
wise young adults. We can only conclude that they produced narratives about their relationship to nature that are interpretable within our enactive cognition framework. All-in-all, and as qualitative studies are supposed to, this study suggests many further studies.

For example, our three concepts - adequacy, connectedness, and beauty - currently have only theoretical and anecdotal evidence. Further research should put these concepts on a more solid grounding. It is also interesting and important for sustainability studies to further investigate how connectedness is triggered. Another topic is the significance of wisdom in improving human-nature relations and the role of peak experiences in nature in relation to a growing understanding of this relation. This study helped to define and exemplify agent adequacy, but we need more studies to learn how to help more people become adequate actors.

All in all, we have helped to elucidate the "Nature of Wisdom" and we have shown that people's connection to nature reflects a deep understanding of life. Perhaps humanity can use this at some point in the future to interact wisely with the environment on which it depends.

\section{References}

Alase, A. (2017). The Interpretative Phenomenological Analysis (IPA): A guide to a good qualitative research Approach. International Journal of Education and Literacy Studies, 5(2), 9-19.

Andringa, T. C., van den Bosch, K. A., \& Vlaskamp, C. (2013). Learning autonomy in two or three steps: linking open-ended development, authority, and agency to motivation. Frontiers in Psychology, 4, 18. http://doi.org/10.3389/fpsyg.2013.00766

Andringa, T. C., van den Bosch, K. A., \& Wijermans, N. (2015). Cognition from life: the two modes of cognition that underlie moral behavior. Frontiers in Psychology, 6(362), 1-18. http://doi.org/10.3389/fpsyg.2015.00362

Angyal, N. (2018). The phenomenology of connectedness (Bachelor thesis). University College Groningen, the Netherlands.

Ardelt, M. (2000). Intellectual versus wisdom-related knowledge: The case for a different kind of learning in the later years of life. Educational Gerontology, 26(8), 771-789.

Ardelt, M. (2003). Empirical assessment of a Three-Dimensional Wisdom Scale. Research on Aging, 25(3), 275-324. http://doi.org/10.1177/0164027503025003004

Di Paolo, E. A., Rohde, M., \& De Jaegher, H. (2010). Horizons for the enactive mind: Values, social interaction, and play. In J. Stewart, O. Gapenne, \& E. A. Di Paolo (Eds.), Enaction towards a new paradigm for cognitive science (pp. 33-87). Cambridge, MA: The MIT Press.

Froese, T., \& Ziemke, T. (2009). Enactive artificial intelligence: Investigating the systemic organization of life and mind. Artificial Intelligence, 173(3-4), 466-500.

Hycner, R. H. (1985). Some guidelines for the phenomenological analysis of interview data. Human Studies, 8(3), 279-303. http://doi.org/10.1007/bf00142995

Lester, S. (1999). An introduction to phenomenological research. Taunton, UK: Stan Lester Developments.

Littlejohn, R. (2003). Daoist philosophy. In J. Fieser \& B. Dowden (Eds.), The Internet encyclopedia of philosophy. Retrieved from http://www.iep.utm.edu/daoism/ 
Maier, S. F., \& Seligman, M. E. P. (1976). Learned helplessness: Theory and evidence. Journal of Experimental Psychology General, 105(1), 3-46. http://doi.org/10.1037/0096-3445.105.1.3

Maslow, A. H. (1954). Motivation and personality. New York: Harper \& Row.

Maslow, A. H. (1962, a). Notes on being-psychology. Journal of Humanistic Psychology, 2(2), 47-71.

Maslow, A. H. (1962, b). Toward a psychology of being. New York: D. van Nostrand Company Inc.

Maturana, H. R., \& Varela, F. J. (1991). Autopoiesis and cognition: the realization of the living. Dordrecht, the Netherlands/Boston, MA: D. Reidel Pub. Co.

Moustakas, C. (1994). Phenomenological research methods. Thousand Oaks, CA: SAGE.

Russell, B. (1938). Power. London: George Allen \& Unwin.

Thompson, E. (2004). Life and mind: From autopoiesis to neurophenomenology. A tribute to Francisco Varela. Phenomenology and the Cognitive Sciences, 3(4), 381-398.

Thompson, E. (2007). Mind in life. Cambridge, MA: Belknap Press.

Varela, F. J., Thompson, E., \& Rosch, E. (1993). The embodied mind: cognitive science and human experience. Cambridge, MA: The MIT Press.

Tjeerd C. Andringa - associate professor, University College Groningen (Netherlands).

Research area: auditory cognition, mutually influencing relationship of the individual and its environment, systems thinking.

E-mail: t.c.andringa@rug.nl

Nikolett Angyal - BA degree in Liberal Arts and Sciences, University College Groningen (Netherlands).

Research area: include human-nature relations and its link to spirituality.

E-mail: angyalnik@gmail.com

\section{Мудрость: связь с природой помогает понимать жизнь}

\section{T. Андринга ${ }^{a}$, Н. Ангиал ${ }^{a}$}

a Университетский колледж Гронингена, Хундипскаде 23/24, 9718 БГ, Гронинген, Нидерландъ

\section{Резюме}

В статье описывается процесс, в ходе которого обладающие мудростью совершеннолетние молодые люди формулируют основанные на интуиции феноменологические знания об их отношении к природе, включающие многочисленные отсылки к современным представлениям о жизни и «базовому познанию». Энактивизм, или «бытие через делание», определяется как способность живого субъекта оставаться в живых посредством выбора правильного поведения из набора способов совладающего поведения и совместного творчества. Люди, вовлеченные в процесс совместного творчества, удовлетворяют свои насущные потребности, одновременно повышая качество среды, от которой зависит удовлетворение этих потребностей. Они способствуют процветанию и динамичному развитию среды, в которой надолго значительно упрощается 
удовлетворение потребностей. Мы называем этот навык «адекватностью субъекта» и связываем его с мудростью. Неадекватные субъекты вновь и вновь сталкиваются с необходимостью удовлетворения потребностей. Они могут попасть в «ловушку совладания», когда применяемые стратегии совладания постепенно ухудшают среду обитания, от которой зависит их жизнь в долгосрочной перспективе. При этом они оказываются заключенными в бесконечный цикл удовлетворения критических потребностей. Мы предлагаем краткие и точные формулировки трех основных понятий отношения «субъект-среда»: адекватность - это способность удовлетворять потребности в краткосрочной и долгосрочной перспективе; связность - это личная связь с другими субъектами или природой в целом, переживаемая как взаимная; красота, истоки которой в способности окружающей среды создавать хрупкое совершенство, являющееся мерой качества окружающей среды. Анализ проведенных интервью показал, что наша (довольно мудрая) группа респондентов оперировала всеми тремя основными понятиями. Мы делаем вывод о том, что наша теоретически разработанная концепция «субъект-среда» находит отражение в реальных примерах отношений между человеком и природой.

Ключевые слова: энактивизм, адекватность субъекта, мудрость, жизнь, природа, красота, связность, пиковые переживания, феноменология, базовое познание, удовлетворение потребностей, самореализация.

Андринга Тьеерд - доцент, преподаватель, Университетский колледж Гронингена (Нидерланды).

Сфера научных интересов: слуховое восприятие, взаимное влияние человека и окружающей среды, системное мышление.

Контакты: t.c.andringa@rug.nl

Ангиал Николетт - бакалавр гуманитарных и естественных наук, Университетский колледж Гронингена (Нидерланды).

Сфера научных интересов: отношения между человеком и природой, их связь с духовностью.

Контакты: angyalnik@gmail.com 